\title{
HSD17B6 wt Allele
}

National Cancer Institute

\section{Source}

National Cancer Institute. HSD17B6 wt Allele. NCI Thesaurus. Code C105153.

Human HSD17B6 wild-type allele is located in the vicinity of $12 q 13$ and is approximately $36 \mathrm{~kb}$ in length. This allele, which encodes 17-beta-hydroxysteroid dehydrogenase type 6 protein, plays a role in androgen catabolism. 